\title{
CORONAVIRUSES: A HISTORICAL PERSPECTIVE
}

\author{
Leslie P. Weiner
}

Departments of Neurology and Microbiology

University of Southern California, School of Medicine

2025 Zonal Avenue, Los Angeles, CA 90033

Coronaviruses are associated with a wide variety of diseases of man and other animals. The importance of this group of viruses in both medical and economic terms has become increasingly evident since the First International Congress was held in Germany in 1980. The application of modern molecular biology and immunology has contributed to new insights into understanding the biology of the viruses and the pathogenesis of the diseases they produce. The number of investigators has also increased over the past several years as evidenced by this Congress which is thus far the largest ever held.

The attraction for veterinary, medical and basic scientists from the very first days of Coronavirology has probably revolved around the marked tropism these viruses have had for specific tissues, particularly the gastrointestinal tract, respiratory system and the nervous system. The first scientific observations were probably made by Baudette and Hudson in 1933 when they described "gasping disease" of chickens and then transmitted the disease to embryos (1,2). Gasping disease was observed to be a devastatingly lethal respiratory disease. The infected embryos were dwarfed and in classical clinical terms were described as being "curled in balls". Subsequently, this virus was identified as infectious bronchitis virus (IBV) which became the prototype of this family of viruses. This description of IBV infected animals being "curled in balls" was brought to my attention about 15 years ago when I was interested in a neurogenic disease of humans, Arthrogryposis multiplex. Arthrogryposis involved fusion of the joints during development and has been attributed to both motor neuron and primary muscle disease. I examined these "curled balls" and indeed found fusion of the embryo joints following infection of IBV, but could not determine pathogenic mechanisms.

In contrast to the IBV, turkey coronavirus or Bluecomb disease and the isolation of "a hepatitis of mice" were gastrointestinal diseases rather than a respiratory infection. Gledhill and Andrewes' isolation of mouse hepatitis virus propelled the field forward (3). The circumstances of their finding focuses on the mysterious ways which prepared minds work. They begin their paper as follows:

"During the autumn of 1950 considerable losses were experienced in breeding stock of a strain of white mice (Parkes (P) strain) maintained at the National Institute for Medical Research. Owing to structural repairs to the animal house, the $\mathrm{P}$ mice had been confined to half the space normally allotted 
to them, and central heating was temporarily unavailable ......" Thus, if it were not for the failure of the usually reliable British heating system, the infective agent they termed mouse hepatitis virus (MHV) would not have produce such widespread devastation. Several important questions were raised with the discovery of MHV. For instance, combined infection with an otherwise harmless murine protozoan, Eperythrozoon coccides, led to a fatal hepatitis. This introduced the idea of activation of latent virus by various forms of stress as important in the pathogenesis of disease $(4,5)$. This activation of MHV had also been suggested to occur when simultaneous infection with murine leukemia viruses was present (6).

Several years prior to the isolation of MHV a virus causing encephalomyelitis with extensive destruction of myelin was isolated from paralyzed mice $(7,8)$. They named the virus JHM after the distinguished Professor at Harvard J.H. Mueller. Subsequently, it was found to be related to MHV (9). It became evident that MHV could be used as a model for both human hepatitis and human demyelinating encephalitides.

The relationship of these murine agents to human hepatitis could not be demonstrated, but it was found that random populations of humans did have cross reacting antibodies (10). It awaited the work of Tyrrell and Bynoe to find that the catarrh from common cold did not yield virus by the means of study available to them at that time, but could still produce colds in volunteers. It remained a mystery until organ cultures of human embryonic trachea or nasal epithelium became available (11). The organ culture (OC) isolates 43 and 38 were isolated. It should be pointed out that the cytopathic effect in such assays was the cessation of the beating cilia in the cultures.

The isolate 229E was found in medical students and cultivated on the human diploid cell line Wi-38 (12). The isolation of the OC agents and 229E allowed for an epidemiological survey showing these agents to be an important human pathogen (13). However, the studies focused on a critical and continuing question of the role of antibody in coronavirus pathogenesis. Antibody levels in serum and secretions had no correlation with resistance to infection. This still remains an enigma.

The recognition that the human respiratory viruses, mouse hepatitis viruses and the prototype infectious bronchitis virus of chickens had a similar appearance resulted in a classic publication in 1968 labeling these viruses coronavirus (14). The paper authored by Almedia, Berry, Cunningham, Hamre, Hofstad, Mallucci, McIntosh and Tyrrell used Tyrrell's description in that the viruses displayed "a characteristic fringe of large, distinctive, petal shaped spikes which resembled a crown like the corona spinarum in religious art" (15). In 1975, the International Committee on the Taxonomy of Viruses name a new family, Coronaviridae, with one genus coronavirus. Additional species have been added including canine coronavirus, feline infectious peritonitis virus, human enteric coronaviruses, transmissible gastroenteritis virus of pigs (TGEV), neonatal calf diarrhea coronavirus (BCV) and rat coronavirus (RCV) (15). These are important pathogens of man and domestic animals as well as important experimental models for the study of cell tropism, genetic resistance and susceptibility of viruses and the important question of latency.

My own exposure to coronaviruses was quite simple. I was thumbing through a volume of the Pathology of Mice and was drawn to the photos of the white matter lesions induced by JHM virus. Encouragement by Neal Nathanson and later by Fred Bang induced me to ask if this model could be used to study the fundamental questions raised in the human disease, multiple sclerosis. These included the following.

1) Are there genetic factors in M.S. which are functionally related to viral clearance, persistent infection and immune cell regulation? 
2) Is the disease M.S. directly related to oligodendrocyte function?

3) What role does the immune response play in the pathogenesis in M.S.? M.S.?

4) Why isn't there significant remyelination following demyelination in

After reading Pappenheimer's review I knew this was indeed an important model (16). In regard to JHM virus, he wrote, "We have noted in our sections a striking hydropic swelling of the oligodendroglia nuclei, and since these cells are regarded as the functional equivalent of the Schwann cells in their trophic influence upon the integrity of the myelin sheaths, we have toyed with the idea that the virus may localize selectively in these elements of the central nervous system, and that their injury may bring about a secondary distintegration of the myelin. Bailey, who has continued to pursue cytologic studies of the JHM virus, writes that he has reached the same conclusion, viz., the primary effect is upon oligodendroglia, but direct proof of such an effect is lacking."

It was Peter Lampert's work on the ultrastructural level and our own pathogenesis studies which proved that indeed this was an infection of oligodendrocytes $(17,18,19,20,21)$. Lampert and his colleagues showed demyelination involves vesicular breakdown of the myelin sheath and that there was active phagocytosis of myelin by invading cell processes. The fundamental nature of this demyelinating model attracted an increasing number of investigators who addressed not only the neurobiological aspects but the question of persistence both in animals (22) and in tissue culture systems $(23,24)$. The study of both latency and persistence was furthered by the development of mutant viruses. Robb et. al. found temperature sensitive mutants which altered the pathogenesis (25). Ts 8 mutant produced demyelination with much higher frequency than wild type JHM (26). Studies were further aided by the development of the murine glial cell line (DBT) which allowed for higher titers and a more accurate assay system than had been previously available (27). The questions of genetic susceptibility, initially raised by Bang and Warwick after they showed that macrophage susceptibility in vitro reflected a genetic determinant for susceptibility in the mouse (28), has become more focused on cellular vulnerability (29) and host immune response genes (30). JHM virus susceptibility locus appears to be on the proximal end of mouse chromosome 7 (30). However, controversy still exists as to whether resistance is inherited by one gene as an autosomal recessive or two genes one dominant and one recessive (31). The pathogenesis of the model was extended when lesions were produced in the rat $(32,33,34,35)$ and particularly when adoptive transfer of an experimental allergic encephalomeylitis - like disease from rats with JHM - induced demyelination (36).

There are still fundamental questions which are now being attacked by hybridoma technology and the methods of recombinant DNA. The immune response genes in resistance have yet to be defined at the single cell genetic level. The characterization of cellular restriction of coronavirus replication which results in persistence is still unanswered. The questions of neurovirulence on a molecular level are still to be addressed although in roads have been made. The multiple size classes of virus specific RNA, subgenomic RNA, the role of leader mRNA and the differential expression of mRNA is being defined in relation to cell tropism and persistence of virus. The question of how viruses cause cell malfunction go beyond cell death by lysis and involves questions of neurobiology such as viral influence on the structural genes involved in myelin production such as proteolipid protein, myelin basic protein (MBP) and myelin associated glycoprotein. The mechanism of remyelination appears to be related to oligodendrocyte DNA synthesis and probably mitosis (37). The induction of this phenomenon is not clear but it probably involved membrane changes induced by phagocytic cells. MBP is expressed during JHM induced demyelination, probably as an initial step in remyelination (38). 
In 1980, Mahy entitled a review of the first International Congress on Coronaviruses, "Coronavirus come of age" (39). This symposium takes the field of animal virology one step further and brings the state of knowledge of molecular biology of coronavirus to levels which will be emulated by those studying the pathogenesis of all virus diseases in man and animals.

\section{References}

1. Baudette, F.R. and Hudson, C.B. New recognized Poultry disease. North American Vet. 1933; 14:50-54.

2. Baudette, F.R. and Hudson, C.B. Cultivation of the virus of infectious bronchitis. J. Am. Vet. Med. Assoc. 1937; 90:51-60.

3. Gledhill, A.W. and Andrewes, C.H. A hepatitis virus of mice. Brit. J. Exp. Path. 1951; 32:559-568.

4. Gledhill, A.W., Dick, G.W.A. and Andrewes, C.H. Production of hepatitis in mice by the combined action of two filterable agents. Lancet 1952; 2:509-511.

5. Gledhill, A.W. and Niven, J.S.F. Latent virus as exemplified by mouse hepatitis virus (MHV). Vet. Rev. Annot. 1955; 1:82-90 ().

6. Nelson, J.B. Acute hepatitis associated with mouse leukemia. I. Pathological features and transmission of the disease. J. Exp. Med. 1952; 96:293-302.

7. Cheever, F.S., Daniels, J.B., Pappenheiner, A.M. and Bailey, O.T. A murine virus (JHM) causing disseminated encephalomyelitis with extensive destruction of myelin. I. Isolation and biological properties of the virus. J. Exp. Med. 1949; 90:181-194.

8. Bailey, O.T., Pappenheimer, A.M., Cheever, F.S. and Daniels, J.B. A murine virus (JHM) causing disseminated encephalomyelitis with extensive destruction of myelin. II. Pathology. J. Exp. Med. 1949; 90:195-212.

9. Niven, J.S.F., Gledhill, A.W., Dick, G.W.A. and Andrewes, C.H. Further light on mouse hepatitis. Lancet 1952; 2:1061.

10. Hartley, J.W., Rowe, W.P., Bloom, H.H. and Turner, H.C. Antibodies to mouse hepatitis viruses in human sera. Proc. Soc. Exp. Biol. Med. 1964; 115:414-418.

11. Tyrrell, D.A.J. and Bynoe, M.L. Cultivation of a novel type of commoncold virus in organ cultures. Brit. Med. J. 1965; 1:1467-1470.

12. Hamre, D. and Procknow, J.J. A new virus isolated from the human respiratory tract. Proc. Soc. Exp. Biol. Med. 1966; 121:190-193.

13 McIntosh, K., Kapikian, A.Z., Hardison, K.A., Hartley, J.W. and Chanock, R.M. Antigenic relationships among coronaviruses of man and between human and animal coronaviruses. J. Immunol. 1969; 102:1109-1118.

14. Tyrrell, D.A.J., Almedia, J.D., Berry, D.M., Cunningham, C.H., Hamre, D., Hofstad, M.S., Malluci, L. and McIntosh, K. Coronavirus. Nature 1968; 220:650.

15. Sturman, L.S. and Holmes, K.V. The Molecular biology of coronaviruses. Adv. Virus Res. 1983; 28:35-112.

16. Pappenheimer, A.W. Pathology of infection with JHM virus. J. Natl. Cancer Inst. 1958; 20:879-891.

17. Weiner, L.P. Pathogenesis of demyelination induced by a Mouse Hepatitis Virus JHM Virus). Arch. Neurol. 1973; 28:298-303.

18. Lampert, P.W., Sims, J.K., Kniazeff, A.J. Mechanism of demyelination in JHM virus encephalomyelitis. Electron microscopic studies. Acta Neuropath. 1973; 24:76-85.

19. Powell, H.C. and Lampert, P.W. Oligodendrocytes and their myelinplasma membrane connections in JHM Mouse Hepatitis virus encephalomyelitis. Laboratory Inves. 1975; 33:440-445.

20 Herndon, R.M., Griffin, D.E., McCormick, U. and Weiner, L.P. Mouse hepatitis virus-induced recurrent demyelination. Arch. Neurology 1975; 32:32-35. 
21. Weiner, L.P. and Stohlman, S.A. Viral models of demyelination. Neurology 1978; 28:111-114.

22. Robb, J.A. and Bond, C.W. Coronaviridae. 1979; 14:193-247.

23. Stohlman, S.A., Sakaguchi, A.Y. and Weiner, L.P. Characterization of the cold-sensitive murine hepatitis virus mutants rescued from latentlyinfected cells by cell fusion. Virology 1979; 98:448-455.

24. Lucas, A., Coulter, M., Anderson, R. Dales, S. and Flintoff, W. In vivo and in vitro models of demyelinating diseases: persistence and host-regulated thermosensitivity in cells of neural derivation infected with mouse hepatitis and measles viruses. Virology 1978; 88:325-337.

25. Robb, J.A., Bond, C.W. and Leibowitz, J.L. Pathogenic murine coronaviruses. III. Biological and biochemical characterization of temperature-sensitive mutants of JHMV. Virology 1979; 91:385-399.

26. Haspel, M.V., Lampert, P.W. and Oldstone, M.B. Temperature-sensitive mutants of mouse hepatitis virus produce a high incidence of demyelination. Proc. Natl. Acad. Sci. USA 1978; 75:4033-4036.

27. Hirano, N., Fujiwara, K. and Matumoto, M. Mouse hepatitis virus (MHV-2): Plaque assay and propagation in mouse cell line DBT cells. Jap. J. Microbiol. 1976; 20:219-225.

28. Bang, F.B. and Warwick, A. Macrophages and mouse hepatitis. Virology 1959; 9:715-717.

29. Collins, A.R., Tunison, L.A. and Knobler, R.L. Mouse hepatitis Virus type 4 infection of primary glial cultures from genetically susceptible and resistent mice. Infect. and Immun. 1983; 40:1192-1197.

30. Knobler, R.L., Taylor, B.A., Wooddell, M.K., Beamer, W.G. and Olstone, M.B.A. Host genetic control of mouse hepatitis virus type-4 (JHM strain) replication. II. The gene locus for susceptibility is linked to Syp-2 locus on mouse chromosome 7. Expl. Clin. Immunogenet. 1984; 1:217-222.

31. Stohlman, S.A. and Frelinger, J.A. Resistance to fatal central nervous system disease by mouse hepatitis virus, strain JHM. I. Genetic analysis. Immunogenetics 1978; 6:277-281.

32. Sorenson, O., Percy, D. and Dales, S. In vivo and in vitro models of demyelinating diseases III. JHM virus infection of rats. Arch. Neurol. 1980; 37:478-484.

33. Koga, M., Wege, H. and ter Meulen, V. Sequence of murine coronavirus JHM induced neuropathological changes in rats. Neuropath. Appl. Neurobiology 1984; 10:173-184.

34. Wege, H., Koga, M., Watanabe, R., Nagushima, K. and ter Meulen, V. Neurovirulence of murine coronavirus JHM temperature sensitive mutants in rats. Infection and Immunity 1983; 39:1316-1324.

35. Parham, D., Tereba, A., Talbot, P.J. Jackson, D.P. and Morris, V.L. Analysis of JHM central nervous system infections in rats. Arch. Neurol. 1986; 43:702-708. 36.Watanabe, R., Wege, H. and ter Meulen, V. Adoptive transfer of EAE-like lesions from rats with coronavirus-induced demyelinating encephalomyelitis. Nature 1983; 305:150-153.

37. Herndon, R.M., Price, D.L. and Weiner, L.P. Regeneration of oligodendroglia during recovery from demyelinating disease. Science 1977; 195:693-694.

38. Kristensson, K., Holmes, K.V., Duchala, C.S. Zeller, N.K., Lazzarini, R.A. and Dubois-Dalcq, M. Increased levels of myelin basic protein transcripts in virus-induced demyelination. Nature 1986; 322:544-547.

39. Mahy, B.W.J. Coronavirus come of age. Nature 1980; 288:536-338. 